\title{
ВОЗМОЖНОСТИ ПЕРВИЧНОЙ ПРОФИЛАКТИКИ ИНСУЛЬТА: РАЗРАБОТКА СТРАТЕГИИ НА ПОПУЛЯЦИОННОМ УРОВНЕ
}

\author{
*Мамедов М.Н., Тогузова 3.А.
}

ФГБУ Государственный научно-исследовательский центр профилактической медицины Минздрава РФ

По данным Британского совета по восстановительной медицине распространенность мозгового инсульта составляет 600-1200 случаев на 100000 чел. Заболеваемость варьирует от 220 до 400 случаев на 100000 чел. В мире от мозгового инсульта ежегодно умирают более 4,6 млн. человек. По данным эпидемиологического исследования NOMASS смертность от ишемического инсульта (наиболее часто встречающаяся форма) в первый год составляет $21 \%$, через 5 лет этот показатель составляет 43\%. В России смертность от инсульта среди мужчин на $30 \%$ меньше по сравнению с инфарктом миокарда, тогда как среди женщин эти показатели сопоставимы.

В последние годы первичная профилактика мозгового инсульта рассматривается как приоритетное направление здравоохранения. Первичная профилактика мозгового инсульта подразумевает коррекцию факторов риска, к числу которых относятся социальные, поведенческие и биологические. Среди модифицируемых факторов важное место в развитии инсульта занимает гипертония, так как между увеличением АД и инсультом выявлена сильная корреляционная связь. Мета-анализ 23 рандомизированных исследований свидетельствует, что адекватная гипотензивная терапия на $32 \%$ снижает риск развития мозгового инсульта. Тиазидные диуретики, ингибиторы АПФ, антагонисты калыция имеют некоторое преимущество в снижении мозгового инсульта. Согласно рекомендациям достижение уровня АД<140/90 мм рт. ст. снижает вероятность развития инсульта. По данным проспективных исследований прекращение курения значительно снижает риск развития ишемического инсульта. У пациентов с сахарным диабетом риск развития инсульта увеличивается от 1,8 до 6 раз. Результаты исследования STENO 2 свидетельствуют, что у пациентов с диабетом и высоким сердечно-сосудистым риском комплексная сахарснижающая, гипотензивная, ан- тиагрегантная и липидснижающая терапия на протяжении 5,5 лет снижает риск сердечно-сосудистых событий на 60\%, а смертность на 57\%. По данным исследования MRFIT с участием 350000 мужчин увеличение уровня холестерина ассоциируется пропорциональным нарастанием смертности, обусловленной ишемическим инсультом. Применение статинов снижает риск развития мозгового инсульта на $21 \%$, тогда эффективность фибратов и никотиновой кислоты в плане предупреждения инсульта не убедительна. Мерцательная аритмия, увеличивающая вероятность развитию тромбоэмболии, увеличивает риск инсульта в 4-5 раз. Применение антикоагулянтной и антиагрегантной терапии у пациентов с мерцательной аритмией снижает риск развития мозгового инсульта. Асимптоматический стеноз сонных артерий также является одним из предикторов развития мозгового инсульта. "Гемодинамически значимый" стеноз (до 60\%) заметно снижает кровоток. У некоторых пациентов применяется каротидная эндартеректомия и ангиопластика (стентирование) каротидных артерий. Заместительная гормональная терапия у женщин в постменопаузе не доказала эффективность в первичной профилактике инсульта.

Изменение образа жизни, включая диету (снижение употребления пищевой соли, увеличение приема овощей и фруктов), и увеличения физической активности (150 минут физической нагрузки умеренной интенсивности в неделю) снижают риск развития мозгового инсульта. Применение аспирина с целью первичной профилактики мозгового инсульта оправдано при наличии высокого риска развития сердечно-сосудистых осложнений.

Таким образом, для реализации популяционной стратегии первичной профилактики мозгового инсульта требуется реализация комплексных и длительных национальных программ.

\section{INSULTLARIN BIRINCILI PROFILAKTIKA IMKANLARI: POPULYASIYYA SOVIYYYSINDO STRATEGIYANIN HAZIRLANMASI}

Mommədov M.N., Toquzova Z.A.

RF Səhiyyə Nazirliyinin Dövlat elmi-tədqiqat profilaktik təbabət mərkəzi

\section{STRATEGY OF PRIMARY PREVENTION OF STROKE ON THE POPULATION LEVEL}

Mamedov M.N., Toguzova Z.A.

FSI "National Research Centre for Preventive Medicine" of the Ministry of Healthcare of the Russian Federation e-mail:mmamedov@mail.ru 